\title{
The old and new therapeutic approaches to the treatment of giardiasis: Where are we?
}

\author{
This article was published in the following Dove Press journal: \\ Biologics:Targets \& Therapy \\ 4 June 2009 \\ Number of times this article has been viewed
}

\author{
Haendel GNO Busatti' \\ Joseph FG Santos ${ }^{2}$ \\ Maria A Gomes' \\ 'Departmento de Parasitologia, ICB, \\ Universidade Federal de Minas Gerais, \\ Belo Horizonte, Brasil; ${ }^{2}$ Hospital \\ Santa Casa de Misericórdia de Belo \\ Horizonte, Minas Gerais, Brasil
}

\begin{abstract}
Giardia lamblia is the causative agent of giardiasis, one of the most common parasitic infections of the human intestinal tract. This disease most frequently affects children causing abdominal pain, nausea, vomiting, acute or chronic diarrhea, and malabsorption syndrome. In undernourished children, giardiasis is a determining factor in retarded physical and mental development. Antigiardial chemotherapy focuses on the trophozoite stage. Metronidazole and other nitroimidazoles have been used for decades as the therapy of choice against giardiasis. In recent years many other drugs have been proposed for the treatment of giardiasis. Therefore, several synthetic and natural substances have been tested in search of new giardicidal compounds. This study is a review of drugs used in in vitro and in vivo tests, and also drugs tested in clinical trials (nonrandomized and randomized).
\end{abstract}

Keywords: Giardia lamblia; treatment; new drugs

\section{Introduction}

Giardia lamblia (syn. Giardia intestinalis, Giardia duodenalis) is a flagellate protozoan which may be found infecting the human small intestine, causing a disease called giardiasis. The symptomatology of human giardiasis is extremely variable, many individuals have the asymptomatic form while some have abdominal pain, nausea, acute or chronic diarrhea - which may last several months, malabsorption and weight loss. ${ }^{1-3}$ The clinical impact seems to be stronger in the first three years of life and in undernourished or immunodeficient individuals. ${ }^{4}$ G. lamblia has often been pointed out as the cause of growth disorders among children, ${ }^{3}$ also with the presence and frequency of diarrhea, for as long as the infection lasts, and the opportunity of reinfection, all constituting essential factors behind children's physical and mental debilitation. ${ }^{5}$

G. lamblia is found in mammals, including human beings, cats, dogs, beavers, and cattle. Giardiasis is transmitted by the ingestion of cysts present in food and water; water dissemination being easier due to cysts resistance to chlorination. ${ }^{6,7}$ Cysts are highly infectious to men. Human volunteers have been experimentally infected with as few as 10 cysts. ${ }^{8}$ These cysts may remain viable in the environment for up to three months under favorable conditions of temperature and humidity. Three aspects are important in the epidemiological context of the disease: the cysts' resistance to the environment, the amount of cysts eliminated by the patients, and the zoonotic aspect of the disease. ${ }^{9}$

Epidemics, in developed countries, have been attributed to an inappropriate water treatment, to its contamination with human or animal feces, particularly in surface
Correspondence: Maria Aparecida Gomes Departamento de Parasitologia, ICB-UFMG, Av. Antonio Carlos, 6627, 3I 270-90I, Belo Horizonte, Minas Gerais, Brasil

$\mathrm{Tel}+553 \mathrm{I} 34092846$

Fax +55 31 34092970

Email magomes@icb.ufmg.br 
water collections and lakes. ${ }^{9}$ Direct transmission from person to person is another infection mechanism, particularly important in collective institutions, such as daycare centers and orphanages, among members of the same family, and between male homosexual partners. ${ }^{10}$ In these populations, giardiasis reaches epidemic levels. $G$. lamblia has a cosmopolitan distribution with an estimated number of $2.8 \times 10^{8}$ cases of infections per year and is thus the most common intestinal parasite in humans in developed countries. ${ }^{11}$ In Asia, Africa, and Latin America, about 200 million people have symptomatic giardiasis with some 500,000 new cases reported each year. ${ }^{12}$ In those countries this disease should be observed carefully, for it contributes substantially to generating mentally and physically impaired adults.

Thompson and colleagues ${ }^{13}$ reviewed publications by several authors who reported genetic variations among Giardia samples isolated from human beings. Such differences are believed to significantly influence giardiasis epidemiology and control, particularly for host susceptibility, virulence, drug sensitivity, antigenicity, and in vivo and in vitro development. ${ }^{5}$ Although some advances have been observed in isolating and characterizing Giardia samples, there are few studies regarding this parasite's chemotherapy. ${ }^{14}$ Resistance to different drugs used in the treatment of this disease has been reported and the number of cases is likely to increase. ${ }^{15-17}$

A variety of chemotherapeutic agents such as 5-nitroimidazole compounds, quinacrine, furazolidone, paromomycin, benzimidazole compounds, nitazoxanide have been used in the therapy for giardiasis. Nevertheless, therapeutic regimens and therapy reviews are little explored. Most drugs used have considerable adverse effects and, most of the time, they are contraindicated. ${ }^{18-20}$ Furthermore, Giardia seems to have a great ability to resist these agents. ${ }^{17,19,21,22}$

In this context, the study of new chemotherapeutic agents plays a fundamental role - along with the reviews of the actually used drugs - in the rationale for treatment of giardiasis on the basis of more consistent data.

Many compounds have shown giardicidal activity in in vivo models or in animal models. In the present review, we have systematically addressed the main in vitro and in vivo studies and prospective trials in human population concerning the treatment of giardiasis.

\section{Methodology}

This is a review of giardiasis treatment in which we analyze the quality of the studies published in the Medline, PubMed, and EMBASE databases from 1966 to September, 2008.
Concentrating only on studies published in English, for each class of study (see below), we looked up the following key words in various combinations: giardia, giardiasis, treatment, therapeutic, therapy, drug, medication, phytotherapy, and chemotherapy. In those studies performed in humans, we did not have an age limit and searched for children and adult patients.

The studies were divided into four classes. Group I: in vitro studies; group II: in vivo studies; group III: clinical trials, nonrandomized, controlled or not; group IV: randomized control trials (RCT), blinded or not.

\section{Inclusion criteria}

We included the following studies: In vitro studies consisting of studies that tested the sensitivity and efficacy of the drugs against Giardia; In vivo studies consisting of studies that tested the efficacy of drugs against Giardia in experimental animals; Nonrandomized clinical trials consisting of studies that tested the efficacy of drugs against Giardia in humans; Randomized controlled clinical trials (RCT) consisting of studies designed to compare the efficacy between different drugs, between drugs and placebo, or to compare different schemes of the same drug in humans. These studies were necessarily randomized and controlled, but not necessarily blinded.

This review was made using two independent reviewers following the same inclusion criteria for searching the articles simultaneously. After they were finished, the reviews were analyzed. Those articles showing up in two reviews were automatically included in the final analysis. The remaining nonconsensual studies were analyzed by a third reviewer for a final decision as to include or exclude an article after the discussion between the first two reviewers was exhausted.

\section{Statistical analysis}

Data are presented as mean \pm standard deviation (confidence interval [CI]), absolute numbers, or percentages. Comparisons between rates of cure of drugs were made using the chi-squared or the Student $t$-test methods. Only variables with $\mathrm{p}<0.05$ were considered significant.

\section{Main results}

In the initial search, 116 in vitro studies, 48 in vivo studies, 87 nonrandomized clinical trials, and 47 RCT were found. After selection for the inclusion criteria, 39 in vitro studies, nine in vivo studies, 23 nonrandomized clinical trials, and 34 RCTs remained (Tables 1-4). 
Table I In vitro studies

\begin{tabular}{|c|c|c|c|}
\hline Year & Drugs/Substances & Activity & Reference \\
\hline 1975 & 2,2-biimidazole & Yes & 23 \\
\hline 1983 & Human milk & Yes & 24 \\
\hline \multirow[t]{4}{*}{1984} & Metronidazole & Yes & 61 \\
\hline & Tinidazole & Yes (+ effective) & \\
\hline & Furazolidone & Yes & \\
\hline & Quinacrin & Yes (- effective) & \\
\hline \multirow[t]{3}{*}{1985} & Bithionol & Yes & 25 \\
\hline & Dichlorophene & Yes & \\
\hline & Hexachlorophene & Yes & \\
\hline 1985 & Clomipramine & Yes & 26 \\
\hline \multirow[t]{2}{*}{1986} & Furazolidone & Yes & 27 \\
\hline & Nitroimidazole & Yes & \\
\hline \multirow[t]{4}{*}{1990} & Azitromicin/Furazolidone & Yes & 28 \\
\hline & Doxiciclin/Mefloquin & Yes & \\
\hline & Doxiciclin/Tinidazole & Yes & \\
\hline & Mefloquin/Tinidazole & Yes & \\
\hline \multirow[t]{2}{*}{ 1991 } & Metronidazole & Yes & 29 \\
\hline & Ornidazole & Yes & \\
\hline I99| & Azitromicin & Yes & 30 \\
\hline 1994 & Serum immune specific & Yes & 31 \\
\hline 1994 & Agglutinin of wheat germ & Yes & 32 \\
\hline 1994 & Derivatives of allicin (diallyl trisulfide) & Yes & 60 \\
\hline \multirow[t]{3}{*}{1995} & Phytotherapics popular in Africa & Yes (+ effective) & 33 \\
\hline & Methanolic extracts cathartics & Yes (- effective) & \\
\hline & Methanolic extracts noncathartics & & \\
\hline \multirow[t]{2}{*}{1995} & Albendazole & Yes (- effective) & 34 \\
\hline & Metronidazole & Yes (+ effective) & \\
\hline 1999 & Derivatives of flavonoid Helianthenum glomeratum & Yes & 59 \\
\hline 2001 & Pyrantel pamoate & Yes & 35 \\
\hline 2001 & Powder of Yucca schidigera & Yes & 36 \\
\hline 2001 & Ciprofloxacin & Yes & 37 \\
\hline \multirow[t]{3}{*}{2002} & Nitazoxanide & Yes (+ effective) & 38 \\
\hline & Albendazole & Yes (+ effective) & \\
\hline & Metronidazole & Yes (- effective) & \\
\hline 2002 & Mucin & Yes & 39 \\
\hline 2002 & Derivatives of isoflavone & Yes & 40 \\
\hline \multirow[t]{2}{*}{2003} & Derivative etylphenylcarbamate & Yes (- effective) & 41 \\
\hline & Albendazole & Yes (+ effective) & \\
\hline 2004 & Gangliosides & Yes & 42 \\
\hline \multirow[t]{2}{*}{2004} & Derivate phenyl-carbamate & Yes (- effective) & 43 \\
\hline & Albendazole & Yes (+ effective) & \\
\hline \multirow[t]{2}{*}{2004} & S-substituted 4,6-dibromo-mercaptobenzimidazole & Yes & 58 \\
\hline & S-substituted 4,6-dichloro-2-mercaptobenzimidazole & Yes & \\
\hline \multirow[t]{2}{*}{2005} & Dodecanoic acid & Yes & 44 \\
\hline & Metronidazole & Yes & \\
\hline 2005 & Arsenic sodium & No & 45 \\
\hline 2005 & Derivatives of Artemisia ludoviciana & Yes & 57 \\
\hline 2005 & Derivatives of flavonoid glycosides & Yes & 56 \\
\hline \multirow[t]{3}{*}{2006} & Derivatives benzimidazoles & Yes (+ effective) & 46 \\
\hline & Albendazole & Yes (++ effective) & \\
\hline & Metronidazole & Yes (- effective) & \\
\hline
\end{tabular}


Table I (Continued)

\begin{tabular}{|c|c|c|c|}
\hline Year & Drugs/Substances & Activity & Reference \\
\hline \multirow[t]{2}{*}{2006} & Nitrotiazol (Nitazoxanide) & Yes & 47 \\
\hline & Metronidazole & Yes & \\
\hline \multirow[t]{2}{*}{2006} & Venom Crotalus durissus terrificus & Yes & 48 \\
\hline & Venom Bothrops jararaca & Yes & \\
\hline 2006 & Propolis & Yes & 49 \\
\hline 2006 & Curcumin & Yes & 50 \\
\hline \multirow[t]{2}{*}{2006} & Metronidazole & Yes & 55 \\
\hline & Furazolidone & Yes (+ effective) & \\
\hline \multirow[t]{3}{*}{2006} & Dorstenia contrajerva & Yes & 54 \\
\hline & Senna villosa & Yes & \\
\hline & Ruta chalepensis & Yes & \\
\hline \multirow[t]{6}{*}{2007} & Metronidazole & Yes (- effective) & 51 \\
\hline & Analogous MTZ-Ms & Yes & \\
\hline & Analogous MTZ-I & Yes & \\
\hline & Analogous MTZ-Br & Yes & \\
\hline & Analogous MTZ-N ${ }_{3}$ & Yes & \\
\hline & Analogous $\mathrm{MTZ}-\mathrm{NH}_{3} \mathrm{Cl}$ & Yes & \\
\hline 2007 & Extracts of blueberry & Yes & 52 \\
\hline \multirow[t]{5}{*}{2007} & Tiliroside & Yes (+ effective) & 53 \\
\hline & Kaempferol-glucopyranoside & Yes & \\
\hline & Astragalin & Yes & \\
\hline & Quercitrin & Yes & \\
\hline & Isoquercitrin & No & \\
\hline
\end{tabular}

In the 39 in vitro studies selected, 55 drugs were tested, $53(96.4 \%)$ showed activity against giardia. Eighteen studies (46.2\%) did not have comparative design with other drugs. Twenty-one studies (53.8\%) compared activity between drugs: $11(52.4 \%)$ compared activity between two drugs, and $10(47.6 \%)$ compared activity between three or more drugs.

The most frequently tested drugs in in vitro studies were: metronidazole (nine studies, 16.4\%), albendazole (five studies, 9.1\%), furazolidone (four studies, 7.3\%), azitromicyn, nitazoxanide, phenyl-carbamate derivatives, tinidazole, and kaempferol (two studies each, 3.6\%). The other drugs had one study each (Table 5).

In the nine in vivo studies selected in which nine drugs were tested, eight (88.9\%) showed activity against Giardia. One of them compared the efficacy between two drugs (11.1\%), and the remaining study tested just one drug (Table 2).

Out of the 23 nonrandomized clinical trials, six studies (26.1\%) had design to compare efficacy between drugs, three (13\%) compared different schemes of the same drug, and three (13\%) compared efficacy between one drug and placebo (nonrandomized). Eleven studies evaluated the effect of one drug without comparing either dosages or efficacy between drugs (see Table 3).
Twelve drugs have been tested in the 23 nonrandomized clinical trials, with an average sample size of $83.3 \pm 53.3$ patients per study (confidence interval $[\mathrm{CI}]=57.2$ to 109.4 ). The mean general rate of cure $(\mathrm{RC})$ per drug was $85.5 \% \pm 16.7$ $(\mathrm{CI}=80.0$ to 91.0$)$. The most frequently tested drugs were: metronidazole (nine studies, $39.1 \%$ ), tinidazole (seven studies, $30.4 \%$ ), ornidazole, and quinacrine (three studies each, 13\%), secnidazole, furazolidone, and berberine (two studies each, 8.7\%) (Table 7). In evaluating drug effectiveness, the following mean rates of cure were found: secnidazole $(\mathrm{RC}=96 \% \pm 2.8)$, ornidazole $(\mathrm{RC}=93.6 \% \pm 1.2)$, tinidazole $(\mathrm{RC}=89.1 \% \pm 8.8)$,

Table 2 In vivo studies

\begin{tabular}{llll}
\hline Year & Drugs/Substances & Activity & Reference \\
\hline I991 & Albendazole & Yes & 62 \\
1993 & New oxadiazoles & Yes (+ effective) & 63 \\
& Metronidazole & Yes (- effective) & \\
1996 & Ivermectin & Yes & 64 \\
1998 & Disulfiram (Antabuse) & Yes & 65 \\
2000 & Oxifendazole & Yes & 66 \\
2001 & Ivermectin & Yes & 67 \\
2002 & Inmunoglobulin (lgA) & Yes & 68 \\
2003 & Vaccine against Giardia & No & 69 \\
2007 & Antioxidant (Antox) & No & 70 \\
\hline
\end{tabular}


Table 3 Nonrandomized clinical trials

\begin{tabular}{|c|c|c|c|}
\hline Year & Drugs/Substances & Activity & Reference \\
\hline 1972 & Berberine & Yes & 71 \\
\hline 1975 & Berberine & Yes & 72 \\
\hline \multirow[t]{4}{*}{1977} & Metronidazole & Yes & 73 \\
\hline & Tinidazole & Yes & \\
\hline & Nimorazol & Yes & \\
\hline & Furazolidone & Yes (- effective) & \\
\hline \multirow[t]{3}{*}{1978} & Tiberal I g BID - GI & Yes & 74 \\
\hline & Tiberal $50 \mathrm{mg} / \mathrm{Kg} /$ single dose - G2 & Yes & \\
\hline & & $\mathrm{SE}>$ group $\mathrm{G} 2$ & \\
\hline 1978 & Metronidazole in four dosage schedules & Yes (+ effective in extended systems) & 75 \\
\hline \multirow[t]{4}{*}{1978} & Metronidazole & & 76 \\
\hline & Tinidazole & Yes (- effective) & \\
\hline & & Yes (+ effective) & \\
\hline & & SE $>$ with metronidazole & \\
\hline \multirow[t]{2}{*}{1978} & Tinidazole & & 77 \\
\hline & Placebo & Yes (+ effective) & \\
\hline \multirow[t]{3}{*}{1978} & Tinidazole single dose highest & & 78 \\
\hline & Tinidazole seven days dose lower & Yes (+ effective) & \\
\hline & & Yes (- effective) & \\
\hline \multirow[t]{3}{*}{1979} & Metronidazole & & 79 \\
\hline & Quinacrine & Yes (+ effective) & \\
\hline & & Yes (- effective) & \\
\hline \multirow[t]{2}{*}{1979} & Ornidazole & & 80 \\
\hline & & Yes & \\
\hline \multirow[t]{7}{*}{1980} & Metronidazole seven days & & 81 \\
\hline & Meronidazole single dose & Yes (- effective) & \\
\hline & Quinacrine & Yes (- effective) & \\
\hline & Tinidazole & Yes (+ effective) & \\
\hline & Ornidazole & Yes (+ effective) & \\
\hline & & Yes (+ effective) & \\
\hline & & SE $>$ with ornidazole & \\
\hline \multirow[t]{4}{*}{1981} & Furazolidone & & 82 \\
\hline & Quinacrine & Yes (+ effective) & \\
\hline & & Yes (- effective) & \\
\hline & & SE $>$ with quinacrine & \\
\hline \multirow[t]{5}{*}{1987} & Metronidazole & & 83 \\
\hline & Tinidazole & Yes & \\
\hline & Ornidazole & Yes & \\
\hline & & Yes & \\
\hline & & Similar & \\
\hline 1987 & Tinidazole & efficiencies & 84 \\
\hline 1995 & Metronidazole & Yes & 85 \\
\hline 1997 & Metronidazole + diloxanide & Yes & 86 \\
\hline \multirow[t]{3}{*}{1997} & Pippali Rasayana & Yes & 87 \\
\hline & Placebo & & \\
\hline & & Yes & \\
\hline 1998 & Albendazole & & 88 \\
\hline 1999 & Secnidazole & Yes & 89 \\
\hline 2000 & Secnidazole & Yes & 90 \\
\hline \multirow[t]{2}{*}{2008} & Metronidazole & Yes & 91 \\
\hline & & Yes & \\
\hline
\end{tabular}

Abbreviations: BID, twice a day; SE, side effects. 
Table 4 Randomized controlled clinical trials

\begin{tabular}{|c|c|c|c|}
\hline Year & Drugs & Activity & Reference \\
\hline 1970 & $\begin{array}{l}\text { Mepacrine } \\
\text { Metronidazole } \\
\text { Furazolidone }\end{array}$ & - & 92 \\
\hline 1977 & $\begin{array}{l}\text { Tinidazole } \\
\text { Metronidazole }\end{array}$ & $\begin{array}{l}\text { Yes }(+ \text { effective and }<\mathrm{SE}) \\
\text { Yes }(- \text { effective and }>\mathrm{SE})\end{array}$ & 93 \\
\hline 1978 & $\begin{array}{l}\text { Tinidazole } \\
\text { Metronidazole }\end{array}$ & - & 94 \\
\hline 1978 & $\begin{array}{l}\text { Tinidazole } \\
\text { Placebo }\end{array}$ & Yes (+ effective) & 95 \\
\hline 1981 & $\begin{array}{l}\text { Tinidazole } \\
\text { Metronidazole }\end{array}$ & Yes - Similar efficacy & 96 \\
\hline 1985 & $\begin{array}{l}\text { Tinidazole } \\
\text { Metronidazole }\end{array}$ & $\begin{array}{l}\text { Yes - Similar efficacy } \\
\text { with appropriate doses }\end{array}$ & 97 \\
\hline 1989 & $\begin{array}{l}\text { Furazolidone } \\
\text { Placebo }\end{array}$ & Yes & 98 \\
\hline 1989 & $\begin{array}{l}\text { Metronidazole } \\
\text { Furazolidone }\end{array}$ & $\begin{array}{l}\text { Yes } \\
\text { Yes }\end{array}$ & 99 \\
\hline 1989 & Menbedazole & No & 100 \\
\hline 1990 & $\begin{array}{l}\text { Metronidazole } \\
\text { Menbendazole }\end{array}$ & $\begin{array}{l}\text { Yes } \\
\text { Yes }\end{array}$ & 101 \\
\hline 1991 & $\begin{array}{l}\text { Metronidazole } \\
\text { Ornidazole }\end{array}$ & Yes - Similar efficacy & 102 \\
\hline 1992 & $\begin{array}{l}\text { Metronidazole } \\
\text { Mebendazole }\end{array}$ & $\begin{array}{l}\text { Yes } \\
\text { Yes }\end{array}$ & 103 \\
\hline 1994 & $\begin{array}{l}\text { Metronidazole } \\
\text { Albendazole }\end{array}$ & $\begin{array}{l}\text { Effectiveness of cure similar } \\
\text { SE }>\text { with metronidazole }\end{array}$ & 104 \\
\hline 1995 & $\begin{array}{l}\text { Metronidazole } \\
\text { Albendazole }\end{array}$ & $\begin{array}{l}\text { Yes } \\
\text { Yes }\end{array}$ & 105 \\
\hline 1995 & $\begin{array}{l}\text { Bacitracin zinc } \\
\text { Bacitracin } \\
\text { Neomycin } \\
\text { Neomycin + Bacitracin zinc }\end{array}$ & $\begin{array}{l}\text { Yes } \\
\text { Yes } \\
\text { Yes } \\
\text { Yes }\end{array}$ & 106 \\
\hline 1995 & $\begin{array}{l}\text { Metronidazole single dose } \\
\text { Metronidazole for five days } \\
\text { Albendazole for five days }\end{array}$ & $\begin{array}{l}\text { Yes } \\
\text { Yes } \\
\text { Yes }\end{array}$ & 107 \\
\hline 1995 & $\begin{array}{l}\text { Metronidazole } \\
\text { Ornidazole } \\
\text { Mebendazole }\end{array}$ & $\begin{array}{l}\text { Yes (effective) } \\
\text { Yes (+ effective) } \\
\text { Yes (- effective) }\end{array}$ & 108 \\
\hline 1999 & $\begin{array}{l}\text { Albendazole } \\
\text { Tinidazole }\end{array}$ & $\begin{array}{l}\text { Yes ( }+ \text { effective) } \\
\text { Yes (- effective) }\end{array}$ & 109 \\
\hline 2001 & $\begin{array}{l}\text { Metronidazole } \\
\text { Mebendazole }\end{array}$ & $\begin{array}{l}\text { Yes } \\
\text { Yes }\end{array}$ & 110 \\
\hline 2001 & $\begin{array}{l}\text { Nitazoxanide } \\
\text { Placebo }\end{array}$ & Yes (+ effective) & 111 \\
\hline 2001 & $\begin{array}{l}\text { Metronidazole } \\
\text { Nitazoxanide }\end{array}$ & Yes - Similar efficacy & 112 \\
\hline 2001 & $\begin{array}{l}\text { Metronidazole + wheat germ } \\
\text { Metronidazole + Placebo }\end{array}$ & $\begin{array}{l}\text { Yes (+ effective) } \\
\text { Yes (- effective) }\end{array}$ & 113 \\
\hline 2002 & $\begin{array}{l}\text { Albendazole } \\
\text { Albendazole + Praziquantel } \\
\text { Tinidazole }\end{array}$ & $\begin{array}{l}\text { Yes (+ effective) } \\
\text { Yes (- effective) } \\
\text { Yes (+ effective) } \\
\text { Albendazole and Tinidazole } \\
\text { with similar effectiveness }\end{array}$ & 114 \\
\hline
\end{tabular}


Table 4 (Continued)

\begin{tabular}{|c|c|c|c|}
\hline Year & Drugs & Activity & Reference \\
\hline \multirow[t]{3}{*}{2002} & Metronidazole & Yes (- effective) & 115 \\
\hline & Ornidazole single dose & Yes (+ effective) & \\
\hline & Ornidazole five days & Yes (+ effective) & \\
\hline \multirow[t]{2}{*}{2003} & Mebendazole & Yes & 116 \\
\hline & Secnidazole & Yes & \\
\hline \multirow[t]{6}{*}{2003} & Albendazole & Yes (- effective) & 117 \\
\hline & Tinidazole & Yes (+ effective) & \\
\hline & Cloroquine & Yes (+ effective ) & \\
\hline & & Tinidazole and Cloroquine & \\
\hline & & with similar effectiveness and & \\
\hline & & greater than Albendazole & \\
\hline \multirow[t]{2}{*}{2004} & Metronidazole & Yes & 118 \\
\hline & Albendazole & Yes & \\
\hline \multirow[t]{2}{*}{2004} & Metronidazole & Yes (- effective) & 119 \\
\hline & Albendazole & Yes (+ effective) & \\
\hline \multirow[t]{3}{*}{2006} & Metronidazole + saccharomyces & Yes (+ effective) & 120 \\
\hline & boulardii & Yes (- effective) & \\
\hline & Metronidazole +placebo & & \\
\hline \multirow[t]{2}{*}{2006} & Mebendazole & Yes & 121 \\
\hline & Quinacrine & Yes & \\
\hline \multirow[t]{2}{*}{2006} & Mebendazole & Yes (- effective) & 122 \\
\hline & Tinidazole & Yes (+ effective) & \\
\hline \multirow[t]{2}{*}{2006} & Metronidazole & Yes (- effective) & 123 \\
\hline & Albendazole & Yes (+ effective) & \\
\hline \multirow[t]{4}{*}{2007} & Vitamin A & Yes & 124 \\
\hline & Zinc & Yes & \\
\hline & Vitamin + zinc & Yes (+ effective) & \\
\hline & Placebo & No & \\
\hline \multirow[t]{2}{*}{2008} & Tinidazole & Yes (+ effective) & 125 \\
\hline & Nitazoxanide & Yes (- effective) & \\
\hline
\end{tabular}

Abbreviation: SE, side effects.

quinacrine $(\mathrm{RC}=85 \% \pm 21.6)$, furazolidone $(\mathrm{RC}=82 \% \pm 14)$, and metronidazole $(\mathrm{RC}=76.6 \% \pm 20.6)$ (Table 8$)$. The metronidazole was the most studied and tested drug for the giardiasis treatment. This drug had greater efficacy in larger doses and in more prolonged regimes ( 5 to 10 days), and achieved a cure rate of $87 \%$ to $100 \%$ in these schemes (Table 9 ).

Out of the 34 RCTs selected for analysis, 23 studies $(67.6 \%)$ had design to compare efficacy between drugs, five $(14.7 \%)$ compared different schemes of the same drug, and five (14.7\%) compared efficacy between one drug and placebo (randomized). One study tested a drug without comparing it with any other drug or placebo. Eight studies (23.5\%) were double-blind studies, five $(62.5 \%)$ compared one drug with placebo, while three $(37.5 \%)$ compared the efficacy between drugs.

Eighteen drugs were tested on the 34 RCTs. The average sample size was $98.9 \pm 38.0$ patients per study $(\mathrm{CI}=83.7$ to 114.1$)$. The mean general rate of cure per drug was $83.0 \% \pm 16.1(\mathrm{CI}=78.4$ to 87.6$)$. Interestingly, the mean rate of cure of the placebo was $25 \%$.

There was no significant difference either in the sample size/patient relationship or in the rate of cure observed between nonrandomized and RCTs studies $(83.3 \times 98.9$ patients/study and $85.5 \% \times 83.0 \% ; \mathrm{p}>0.05)$.

The most frequently tested drugs in RCTs were: metronidazole (21 studies, 61.8\%), tinidazole (10 studies, 29.4\%), albendazole (nine studies, 26.5\%), mebendazole (eight studies, $23.5 \%$ ), ornidazole, furazolidone, and nitazoxanide (three studies each, 8.8\%) (Table 10).

Among drugs showing greater effectiveness, the following mean rates of cure were found: ornidazole $(\mathrm{RC}=97.6 \% \pm 2.5)$, tinidazole $(\mathrm{RC}=91.1 \% \pm 6.3)$, metronidazole $(\mathrm{RC}=81.5 \% \pm 18.6)$, nitazoxanide $(\mathrm{RC}=79.7 \% \pm 1.8)$, and albendazole $(\mathrm{RC}=73.4 \% \pm 19.8)$ (Table 11). According to the nonrandomized clinical trials, metronidazole was the drug most frequently studied and 
Table 5 In vitro studies: drugs more frequently tested

\begin{tabular}{|c|c|c|c|}
\hline & Drugs/Substances tested & Number of studies & Observation \\
\hline I & 2,2-biimidazole & I & - \\
\hline 2 & Human milk & 1 & - \\
\hline 3 & Bithionol & 1 & - \\
\hline 4 & Dichlorophene & I & - \\
\hline 5 & Hexachlorophene & I & - \\
\hline 6 & Clomipramine & I & - \\
\hline 7 & Furazolidone & 4 & $*$ \\
\hline 8 & Nitroimidazole & I & - \\
\hline 9 & Azitromicin & 2 & $*$ \\
\hline 10 & Doxiciclin & I & - \\
\hline II & Mefloquin & I & - \\
\hline 12 & Tinidazole & 2 & $*$ \\
\hline 13 & Metronidazole & 9 & $*$ \\
\hline 14 & Ornidazole & I & - \\
\hline 15 & Serum immune specific & I & - \\
\hline 16 & Agglutinin of wheat germ & I & - \\
\hline 17 & Methanolic extracts cathartics & I & \# \\
\hline 18 & Methanolic extracts noncathartics & I & \# \\
\hline 19 & Albendazole & 5 & $*$ \\
\hline 20 & Pyrantel pamoate & I & - \\
\hline 21 & Powder of Yucca schidigera & I & - \\
\hline 22 & Ciprofloxacin & I & - \\
\hline 23 & Nitazoxanide (Nitrotiazol) & 2 & $*$ \\
\hline 24 & Mucin & I & - \\
\hline 25 & Derivatives of isoflavone & I & - \\
\hline 26 & Derivative etylphenylcarbamate & 2 & * \\
\hline 27 & Gangliosides & I & - \\
\hline 28 & Dodecanoic acid & I & - \\
\hline 29 & Arsenic sodium & I & - \\
\hline 30 & Derivatives benzimidazoles & I & - \\
\hline 31 & Venom Crotalus durissus terrificus & I & - \\
\hline 32 & Venom Bothrops jararaca & I & - \\
\hline 33 & Propolis & I & - \\
\hline 34 & Curcumin & I & - \\
\hline 35 & Analogous MTZ-Ms & I & - \\
\hline 36 & Analogous MTZ-I & I & - \\
\hline 37 & Analogous MTZ-Br & I & - \\
\hline 38 & Analogous MTZ- $\mathrm{N}_{3}$ & 1 & - \\
\hline 39 & Analogous MTZ- $\mathrm{NH}_{3} \mathrm{Cl}$ & I & - \\
\hline 40 & Extracts of blueberry & I & - \\
\hline 41 & Tiliroside & I & - \\
\hline 42 & Kaempferol-glucopyranoside & 2 & $*$ \\
\hline 43 & Astragalin & I & - \\
\hline 44 & Quercitrin & I & - \\
\hline 45 & Isoquercitrin & I & - \\
\hline 46 & Dorstenia contrajerva & I & - \\
\hline 47 & Senna villosa & 1 & - \\
\hline 48 & Ruta chalepensis & 1 & - \\
\hline
\end{tabular}


Table 5 (Continued)

\begin{tabular}{llll}
\hline & Drugs/Substances tested & Number of studies & Observation \\
\hline 49 & Derivatives of flavonoid glycosides & I & - \\
50 & Derivatives of Artemisia ludoviciana & I & - \\
51 & S-substituted 4,6-dibromo mercaptobenzimidazole & I & - \\
52 & S-substituted 4,6-dichloro-2-mercaptobenzimidazole & I & - \\
53 & Derivatives of flavonoid Helianthenum glomeratum & I & - \\
54 & Derivatives of allicin (diallyl trisulfide) & I & - \\
\hline 5 & Quinacrin & I & - \\
\hline
\end{tabular}

Notes: "phytotherapies are popular in Africa; *Drugs more frequently tested.

tested on the RCTs. Likewise, this drug had greater efficacy with larger doses and with more prolonged regimes ( 5 to 10 days), reaching cure rates of $89 \%$ to $97 \%$ with these schemes (Table 12).

On the RCTs, tinidazole and ornidazole were the drugs which showed good efficacy using a single-dose scheme. Albendazole shown great variability in efficacy, not only in a single dose ( $\mathrm{RC}=50 \%$ to $97 \%$ ), but also in prolonged regimes ( $\mathrm{RC}=62 \%$ to $90 \%$ ).

The side effects were poorly described in the majority of studies in the nonrandomized control trials, and they ranged from none to $59 \%$, although they were mild and transient. As in nonrandomized clinical trials, the prevalence of side effects were poorly described in the majority of RCTs studies, ranging from few or absent to $70 \%$, and were also mild and transient.

\section{Discussion}

In 1957, the Rhone-Poulenc laboratories synthesized 1-( $\beta$-hydroxyethyl)-2-methyl-5-nitroimidazole (metronidazole) by manipulating the chemical structure of 2-nitroimidazole ${ }^{126}$ and this proved to be a highly effective agent against Trichomonas vaginalis infections. ${ }^{127}$ In 1962, Darbon and colleagues ${ }^{128}$ reported that this could also be used in treatments against giardiasis. Thus, since it was discovered, metronidazole and other 5-nitroimidazoles - such as secnidazole, ornidazole, and tinidazole - are used by physicians to treat G. lamblia infections in addition to infections by other microorganisms. Nowadays, metronidazole is the most used drug to treat giardiasis worldwide; including in the USA. ${ }^{129}$ However, the number of new drugs is increasing.

Doing this review, we found out that there were a high number of studies regarding the giardiasis treatment, even with the methodology used in the present study. However, the quality of them was very poor, mainly regarding their primary goal, their design, and sample size; in addition to a great heterogeneity detected between studies.
In all categories of studies, 298 were initially included (in vitro, in vivo, nonrandomized clinical trials, and RCTs), which, after selection, comprised 105 studies - representing $35.2 \%$ - that constituted the sample for the analysis. It is important to point out that we used relatively liberal criteria to select the articles, and the search was done only in the most important databases, comprising journals with more restricted and rigorous publication criteria.

One hundred and sixteen references to in vitro studies were found, which comprised 39 (33.6\%) studies that constituted the data bank for analysis. Based on this, 50 drugs were evaluated, 48 (96\%) of which showing activity against Giardia. Most of these studies had design to compare drugs among themselves ( $53 \%$ ): $52.4 \%$ to compare two drugs, and $47.6 \%$ to compare three or more drugs.

Many of the studies with two or more drugs did not necessarily compare the efficacy between drugs, but just analyzed and described the activity of the drugs without comparing their efficacy.

Although the number of known drugs tested was larger, we found out that the most widely tested drugs were metronidazole, albendazole, and furazolidone, and that the new drugs were larger in number, each with few studies (Table 5). In this context, several in vitro studies have been carried out in order to search for new substances with antigiardial activity. This way, many methods have been described aiming at determining the antigiardial activity of drugs in vitro. ${ }^{4,19,64,130-133}$ However, some of these are laborious and require long and hard work; furthermore, they are very difficult to reproduce for they lack standardization.

In the initial search for new drugs with antigiardial activity, 48 in vivo studies were found but only nine (18.8\%) constituted the data bank for analysis, according to the inclusion criteria. Ten drugs were tested in these studies, and eight (80\%) were active against Giardia. The majority of studies did not compare drugs, but just tested the activity of one drug against Giardia (Tables 2 and 6). 
Table 6 In vivo studies: drugs more frequently tested

\begin{tabular}{llll}
\hline & Drugs tested & Number of studies & Observation \\
\hline I & Albendazole & I & - \\
2 & News oxadiazoles & I & - \\
3 & Metronidazole & I & - \\
4 & Ivermectin & 2 & $*$ \\
5 & Disulfiram (Antabuse) & I & - \\
6 & Oxifendazole & I & - \\
7 & Inmunoglobulin (IgA) & I & - \\
8 & Vaccine against Giardia & I & - \\
9 & Antioxidant (Antox) & I & - \\
\hline
\end{tabular}

Note: *Drugs more frequently tested.

Again, the various models used and the absence of standardized design, besides the heterogeneity of these studies, make the comparative analysis difficult. In this context, several in vivo experimental models have been proposed. They are often beavers, young and adult rats, ${ }^{134-137}$ rabbits, ${ }^{138}$ dogs, ${ }^{139}$ cats, ${ }^{140}$ mice,,${ }^{141,142}$ and gerbils. ${ }^{143,144}$ However, the best results have only been obtained in gerbil experimental models. Gerbil (Meriones unguiculatus) is considered by several researchers the most appropriate experimental model for giardiasis due to its size, facility to handle, high susceptibility to infections, and large shedding of cysts in their feces. ${ }^{143-148}$ Thus, we consider that the absence of standardized methods between studies limited the comparative analysis.

When we analyze the studies in human beings (nonrandomized trials and randomized control trials), we find great heterogeneity among them, besides the poor quality of their methodology.

Table 7 Drugs more frequently tested in nonrandomized clinical trials

\begin{tabular}{llll}
\hline & Drugs tested & Number of studies & Observation \\
\hline 1 & Berberine & 2 & $*$ \\
2 & Metronidazole & 9 & $*$ \\
3 & Tinidazole & 7 & $*$ \\
4 & Nimorazole & 1 & - \\
5 & Furazolidone & 2 & $*$ \\
6 & Tiberal & 1 & - \\
7 & Quinacrin & 3 & $*$ \\
8 & Ornidazole & 3 & $*$ \\
9 & Diloxanide & 1 & - \\
10 & Pippali Rasayana & 1 & - \\
11 & Albendazole & 1 & - \\
12 & Secnidazole & 2 & $*$ \\
\hline
\end{tabular}

Note: *Drugs more frequently tested.
Table 8 Mean rate of cure of drugs more tested in nonrandomized clinical trials

\begin{tabular}{llll}
\hline & Drugs tested & $\begin{array}{l}\text { Number } \\
\text { of studies }\end{array}$ & $\begin{array}{l}\text { Mean rate of } \\
\text { cure } \% \pm \text { SD }(\mathbf{C l})\end{array}$ \\
\hline 1 & Metronidazole & 9 & $76.6 \pm 20.6(64.9-88.3)$ \\
2 & Tinidazole & 7 & $89.1 \pm 8.8(83-92.5)$ \\
3 & Ornidazole & 3 & $93.6 \pm 1.2(92.2-95)$ \\
4 & Quinacrin & 3 & $85 \pm 21.6(63.8-100)$ \\
5 & Secnidazole & 2 & $96 \pm 2.8(92.0-99.9)$ \\
6 & Furazolidone & 2 & $82 \pm 14.0(62.5-100)$ \\
\hline
\end{tabular}

Note: *Drugs more frequently tested.

Abbreviations: $\mathrm{Cl}$, confidence interval; SD, standard deviation.

No references selected were similar in design, dosages, duration of treatment, and results, which led to a great difficulty in grouping them according to the tested drug (required time or percentage of fecal cure, independent of duration of treatment). These findings agree with those by Zaat and colleagues. ${ }^{149}$

In the nonrandomized clinical trials, slightly more than a quarter of studies compared the efficacy between drugs, whereas $47.8 \%$ tested drugs without comparing them to a placebo or to another drug, just appraising their efficacy in treated patients versus untreated patients. Only 13\% compared a drug to a placebo.

On the RCTs, we find that two thirds of the studies $(67.6 \%)$ compared the efficacy between drugs; however, only $14.7 \%$ compared drugs to a placebo. Here, just one study did not include a comparison between drugs. About half the nonrandomized clinical trials tested different dosages of drugs (assessment of therapeutic schemes), whereas the RCTs were comparative studies of efficacy between drugs, with few studies using a placebo for comparing the efficacy of drugs (14.7\%).

Regarding the number of drugs tested, we built an extensive list of them: 55 drugs in 39 in vitro studies, nine

Table 9 More effective doses of drugs tested in nonrandomized clinical trials

\begin{tabular}{lll}
\hline Drugs & Unit & Recommended doses \\
\hline Metronidazole & $\mathrm{mg} / \mathrm{Kg} / \mathrm{day}$ & $\mathrm{I} 5-25$ TID -5 to 10 days \\
& $\mathrm{mg}$ & $200-500$ TID -5 to 10 days \\
Tinidazole & $\mathrm{mg}$ & $\mathrm{I}-2$ MID - One day \\
Ornidazole & $\mathrm{mg}$ & 2 MID - One day \\
Quinacrine & $\mathrm{mg}$ & I00 TID -5 days \\
Secnidazole & $\mathrm{mg} / \mathrm{Kg}$ & 30 MID - One day \\
\hline
\end{tabular}

Abbreviations: TID, three times a day; MID, once a day. 
Table I0 Drugs more frequently tested in randomized control clinical trials

\begin{tabular}{llll}
\hline & Drugs tested & $\begin{array}{l}\text { Number } \\
\text { of studies }\end{array}$ & Observation \\
\hline 1 & Mepacrine & I & - \\
2 & Metronidazole & 21 & $*$ \\
3 & Furazolidone & 3 & $*$ \\
4 & Tinidazole & 10 & $*$ \\
5 & Mebendazole & 8 & $*$ \\
6 & Ornidazole & 3 & $*$ \\
7 & Albendazole & 9 & $*$ \\
8 & Bacitracin zinc & 1 & - \\
9 & Neomycin & 1 & - \\
10 & Nitazoxanide & 3 & $*$ \\
11 & Wheat germ & 1 & - \\
12 & Praziquantel & 1 & - \\
13 & Cloroquine & 1 & - \\
14 & Secnidazole & I & - \\
15 & Saccharomyces boulardii & I & - \\
16 & Quinacrin & 1 & - \\
17 & Vitamin A & I & - \\
18 & Zinc & 2 & - \\
\hline
\end{tabular}

Note: *Drugs more frequently tested.

drugs in nine in vivo studies, 12 drugs in 23 nonrandomized trials, and 18 drugs in 50 RCTs (Tables 1-4).

Regarding the sample size, in human studies, we found a comparatively small sample size in both nonrandomized and RCTs studies. We found a higher sample size in the RCTs as compared to the nonrandomized studies, though not statistically significant $(98.9 \times 83.3$ patients study; $\mathrm{p}<0.05$ ).

These findings show a great number of studies in which the external validation, and, consequently, the generalizability of the results is jeopardized. Numerous confounding factors make the analysis of these studies difficult, mainly due to problems in controlling some variables in the population studied.

The most frequently tested drugs in the present review are listed in Tables 5, 6, 7, and 10. We find that the most used drugs in human studies were all tested in in vitro studies, but not all drugs tested in in vivo studies were tested in human studies, although the number of drugs in the in vivo studies was as low as 10 drugs. Metronidazole was the most frequently tested drug. They were tested in $16.4 \%$ of in vitro studies, in $11.1 \%$ of in vivo studies, in $39.1 \%$ of nonrandomized studies, and in $61.8 \%$ of RCTs. Thus, this drug was the main drug in the available arsenal for giardiasis treatment, constituting a
Table I I Mean rate of cure of drugs in randomized control clinical trials

\begin{tabular}{llll}
\hline & Drugs tested & $\begin{array}{l}\text { Number } \\
\text { of studies }\end{array}$ & $\begin{array}{l}\text { Mean rate of } \\
\text { cure \% } \pm \text { SD }(\mathrm{Cl})\end{array}$ \\
\hline 1 & Metronidazole & 21 & $81.5 \pm 18.6(71.0-92.0)$ \\
2 & Tinidazole & 10 & $91.1 \pm 6.3(87.2-95.0)$ \\
3 & Albendazole & 9 & $73.4 \pm 19.8(58.7-88.1)$ \\
4 & Mebendazole & 8 & $65.6 \pm 17.3(50.4-80.8)$ \\
5 & Ornidazole & 3 & $97.6 \pm 2.5(95.4-99.8)$ \\
6 & Nitazoxanide & 3 & $79.7 \pm 1.8(77.2-82.2)$ \\
\hline
\end{tabular}

Note: *Drugs more frequently tested.

Abbreviations: $\mathrm{Cl}$, confidence interval; $\mathrm{SD}$, standard deviation.

reference in relation to other drugs. This finding corroborates other reviews. ${ }^{149,150}$

When only the nonrandomized and RCTs studies were analyzed, the two most tested drugs were metronidazole and tinidazole. However, mebendazole and albendazole were among the most tested in RCTs, and they were barely tested in nonrandomized studies.

We also noticed that the "new drugs" for giardiasis treatment were barely tested in all categories of studies reviewed in this work, either in in vitro studies or in RCTs. This demonstrates the difficulty in adequately testing one drug for giardiasis in order to have alternatives in case of resistance to one of the therapeutic schemes.

In spite of the large amount of drugs used in antigiardial therapy, some resistance has been reported regarding different therapeutic regimens, and this resistance has been mentioned by clinicians. ${ }^{18,20,151}$ This characteristic makes Giardia a fearful microorganism, mainly among undernourished people, in whom the malabsorption syndrome is more common. In this scenario, developing and screening new antigiardial drugs seems to be a priority.

Table 12 More effective doses of drugs tested in randomized clinical trials

\begin{tabular}{lll}
\hline Drugs & Unit & Recommended doses \\
\hline Metronidazole & $\mathrm{mg} / \mathrm{Kg} /$ day & I5-50 TID -5 to 10 days \\
& $\mathrm{mg}$ & $500-750$ TID -5 to 10 days \\
Tinidazole & $\mathrm{mg}$ & $2 \mathrm{MID}-$ One dose \\
Albendazole & $\mathrm{mg} / \mathrm{Kg} /$ day & 50 MID - One dose \\
& $\mathrm{mg}$ & $400 \mathrm{MID}-$ One day \\
& $\mathrm{mg}$ & $400 \mathrm{MID}-5$ days \\
Mebendazole & $\mathrm{mg} / \mathrm{Kg} /$ day & 10 MID -5 days \\
Ornidazole & $\mathrm{mg}$ & $200 \mathrm{TID}-5$ days \\
Nitazoxanide & $\mathrm{mg} / \mathrm{Kg} /$ day & $20-40 \mathrm{MID}-\mathrm{I}$ to 5 days \\
\hline
\end{tabular}

Abbreviations: TID, three times a day; MID, once a day. 
In order to analyze the optimal dosages for the most tested drugs, we evaluated the mean rate of cure for all (Tables 8 and 11). We found out that the most tested drugs and those with more efficacy in studies with human beings were tinidazole and metronidazole; though ornidazole had a great efficacy not only in nonrandomized but also in RCTs. However, ornidazole was tested in only six studies in the present review (three nonrandomized and three RCTs).

The optimal dosages found in this review for most drugs were those that achieved the best rate of cure for each drug separately. Tables $8,9,11$, and 12 show the most widely used drugs and their mean rate of cure, along with the optimal dosages for each. Comparing the mean rate of cure between the most tested drugs, we detected a similar efficacy among them, none being better than the others, except for mebendazole in the RCTs.

The analyses of the side effects have been poorly appraised and documented in most studies. Apparently, they have been similar in all studies, and no drug was reported to be unsafe, causing only mild to moderate and transient side effects.

However, regarding the new drugs, only those tested in human beings had their side effects described, but we have few data about it at the moment.

In summary, in this review we found many studies on the giardiasis treatment; however, most of them presented various problems concerning the sample size, methodology, design, among others.

Moreover, the number of drugs tested was large, with a relative higher number of new drugs listed, mainly in the in vitro studies, and a lower number in the studies with humans. However, these new drugs were barely tested as compared to the old drugs, mainly in humans, increasing the need for new studies to provide standardization for the evaluation of antigiardial drugs. This can provide more accuracy and quickness for approval, as well as an adequate use not only for the new drugs but also the old ones.

\section{Conclusion}

In conclusion, this review raises some problems regarding the evidence for using old and new antigiardial drugs, in relation to the quality of previous and future studies. Yet, one must point out that the drugs in use nowadays are the most widely tested and that they are safe, although we must rethink and further study the problem of their increasing resistance.

\section{Acknowledgments}

We are grateful for the financial support of FAPEMIG. The authors report no conflicts of interest in this work.

\section{References}

1. Meyer EA, Radulescu S. Giardia and Giardiasis. Adv Parasitol. 1979;17:1-47.

2. Ungar BLP, Yolken RH, Nash TE, et al. Enzyme-linked immunosorbent assay for the detection of Giardia lamblia in fecal specimens. J Infect Dis. 1984;149(1):90-97.

3. Goldin AJ, Werner APT, Aguilera X, et al. Efficient diagnosis of giardiasis among nursery and primary school children in Santiago, Chile by capture ELISA for the detection of fecal Giardia antigens. Am J Trop Med Hyg. 1990;42(6):538-545.

4. Farthing MJG. Host parasite interactions in human Giardiasis. Quart J Med. 1989;70(263):191-204.

5. Thompson RCA, Reynoldson JA, Mendis AHW. Giardia and Giardiasis. Adv Parasitol. 1993;32:71-160.

6. Fayer R. Cryptosporidium: a water-borne zoonotic parasite. Vet Parasitol. 2004;126(1-2):37-56.

7. Thompson RC. The zoonotic significance and molecular epidemiology of Giardia and giardiasis. Vet Parasitol. 2004;126(1-2):15-35.

8. Rendtorff RC. The experimental transmission of human intestinal protozoan parasites II. Giardia lamblia cysts given in capsules. Am J Hyg. 1954;59(2):209-220.

9. Hunter PR, Thompson RC. The zoonotic transmission of Giardia and Cryptosporidium. Int J Parasitol. 2005;35(11-12):1181-1190.

10. Ungar BLP, Yolken RH, Nash TE, et al. Enzyme-linked immunosorbent assay for the detection of Giardia lamblia in fecal specimens. J Infect Dis. 1984;149(1):90-97.

11. Lane S, Lloyd D. Current trends in research into the waterborne parasite Giardia. Crit Rev Microbiol. 2002;28(2):123-147.

12. World Health Organization. The World Health Report 1996. Fighting Disease Fostering Development. Geneva, Switzerland: World Health Organization; 1996.

13. Thompson RCA, Lymbery AJ, Meloni BP. Genetic variation in Giardia Kunstler, 1882: taxonomic and epidemiological significance. Protozool Abstracts. 1990;14:1-28.

14. Wright JM, Dunn LA, Upcroft P, et al. Efficay of antigiardial drugs. Expert Opin Drug Saf. 2003;2:529-541.

15. Johnson PJ. Metronidazole and drug resistance. Parasitol Today. 1993;9(5):183-186.

16. Upcroft JA, Dunn LA, Wright JM, et al. 5-Nitroimidazole drugs effective against metronidazole-resistant Trichomonas vaginalis and Giardia duodenalis. Antimicrob Agents Chemother. 2006;50(1):344-347.

17. Long KZ, Rosado JL, Montoya Y, et al. Effect of vitamin A and zinc supplementation on gastrointestinal parasitic infections among Mexican children. Pediatrics. 2007;120(4):846-855.

18. Ellis JE, Wingfield JM, Cole D, et al. Oxygen affinities of metronidazoleresistant and -sensitive stocks of Giardia intestinalis. Int J Parasitol. 1993;23(1):35-39.

19. Upcroft JA, Campbell RW, Benakli K, et al. Efficacy of new 5-nitroimidazoles against metronidazole-susceptible and resistant Giardia, Trichomonas, and Entamoeba spp. Antimicrob Agents Chemother. 1999;43(1):73-76.

20. Petri W. Therapy of intestinal protozoa. Trends Parasitol. 2003;19(11): 523-526.

21. Boreham PFL, Phillips RE, Shepherd RW. Altered uptake of metronidazole in vitro by stocks of Giardia intestinalis with different drug sensitivities. Trans R Soc Trop Med Hyg. 1988;82(1):104-106.

22. Upcroft JA, Upcroft P, Boreham PFL. Drug resistance in Giardia intestinalis. Int J Parasitol. 1990;20(4):489-496.

23. Melloni P, Metelli R, Bassini DF, et al. Snythesis and antiprotozoal activity of nitro derivatives of 2, 2'-biimidazole. Arzneimittelforschung. 1975;25(1):9-14.

24. Gillin FD, Reiner DS, Wang CS. Human milk kills parasitic intestinal protozoa. Science. 1983;221(4617):1290-1292.

25. Takeuchi $\mathrm{T}$, Kobayashi $\mathrm{S}$, Tanabe $\mathrm{M}$, et al. In vitro inhibition of Giardia lamblia and Trichomonas vaginalis growth by bithionol, dichlorophene, and hexachlorophene. Antimicrob Agents Chemother. 1985;27(1):65-70. 
26. Weinbach EC, Costa JL, Wieder SC. Antidepressant drugs suppress growth of the human pathogenic protozoan Giardia lamblia. Res Commun Chem Pathol Pharmacol. 1985;47(1):145-148.

27. McIntyre P, Boreham PF, Phillips RE, et al. Chemotherapy in giardiasis: clinical responses and in vitro drug sensitivity of human isolates in axenic culture. J Pediatr. 1986;108(6):1005-1010.

28. Crouch AA, Seow WK, Whitman LM, et al. Sensitivity in vitro of Giardia intestinalis to dyadic combinations of azithromycin, doxycycline, mefloquine, tinidazole and furazolidone. Trans $R$ Soc Trop Med Hyg. 1990;84(2):246-248.

29. Majewska AC, Kasprzak W, De Jonckheere JF, et al. Heterogeneity in the sensitivity of stocks and clones of Giardia to metronidazole and ornidazole. Trans R Soc Trop Med Hyg. 1991;85(1):67-69.

30. Boreham PFL, Upcroft JA. The activity of azithromycin against stocks of Giardia intestinalis in vitro and in vivo. Trans R Soc Trop Med Hyg. 1991;85(5):620-621.

31. Belosevic M, Faubert GM, Dharampaul S. Antimicrobial action of antibodies against Giardia muris trophozoites. Clin Exp Immunol. 1994;95(3):485-489.

32. Ortega-Barria E, Ward HD, Keusch GT, et al. Growth inhibition of the intestinal parasite Giardia lamblia by a dietary lectin is associated with arrest of the cell cycle. J Clin Invest. 1994;94(6):2283-2288.

33. Johns T, Faubert GM, Kokwaro JO, et al. Anti-giardial activity of gastrointestinal remedies of the Luo of east Africa. J Ethnopharmacol. 1995;46(1):17-23.

34. Farbey MD, Reynoldson JA, Thompson RC. In vitro drug susceptibility of 29 isolates of Giardia intestinalis from humans as assessed by anadhesion assay. Int J Parasitol. 1995;25(5):593-599.

35. Campanati L, Gadelha AP, Monteiro-Leal LH. Electron and videolight microscopy analysis of the in vitro effects of pyrantel pamoate on Giardia lamblia. Exp Parasitol. 2001;97(1):9-14.

36. McAllister TA, Annett CB, Cockwill CL, et al. Studies on the use of Yucca schidigera to control giardiasis. Vet Parasitol. 2001;97(2):85-99.

37. Sousa MC, Poiares-da-Silva J. The cytotoxic effects of ciprofloxacin in Giardia lamblia trophozoites. Toxicol In Vitro. 2001;15(4-5): 297-301

38. Cedillo-Rivera R, Chávez B, González-Robles A, et al. In vitro effect of nitazoxanide against Entamoeba histolytica, Giardia intestinalis and Trichomonas vaginalis trophozoites. J Eukaryot Microbiol. 2002;49(3):201-208.

39. Roskens H, Erlandsen SL. Inhibition of in vitro attachment of Giardia trophozoites by mucin. J Parasitol. 2002;88(5):869-873.

40. Mineno T, Stanford KM, Walker LA, et al. Solution-phase parallel synthesis of an isoflavone library for the discovery of novel antigiardial agents. Comb Chem High Throughput Screen. 2002;5(6):481-487.

41. Jiménez-Cardoso E, Flores-Luna A, Angeles E, et al. In vitro antigiardial activity of IRE-6A and IRE-7B, two ethyl-phenylcarbamate derivatives. Rev Invest Clin. 2003;55(4):444-447.

42. Suh M, Belosevic M, Clandinin MT. Dietary lipids containing gangliosides reduce Giardia muris infection in vivo and survival of Giardia lamblia trophozoites in vitro. Parasitology. 2004;128(Pt 6):595-602.

43. Jiménez-Cardoso E, Flores-Luna A, Pérez-Urizar J. In vitro activity of two phenyl-carbamate derivatives, singly and in combination with albendazole against albendazole-resistant Giardia intestinalis. Acta Trop. 2004;92(3):237-244.

44. Rayan P, Stenzel D, McDonnell PA. The effects of saturated fatty acids on Giardia duodenalis trophozoites in vitro. Parasitol Res. 2005;97(3):191-200.

45. Escudero-Lourdes C, Martínez FD, Medina de la Garza CE, et al. Effect of oral chronic intoxication with sodium arsenite on murine giardiasis. Proc West Pharmacol Soc. 2005;48:92-99.

46. Navarrete-Vázquez G, Rojano-Vilchis Mde M, Yépez-Mulia L, et al. Synthesis and antiprotozoal activity of some 2-(trifluoromethyl)-1Hbenzimidazole bioisosteres. Eur J Med Chem. 2006;41(1):135-141.

47. Müller J, Rühle G, Müller N, et al. In vitro effects of thiazolides on Giardia lamblia WB clone C6 cultured axenically and in coculture with Caco2 cells. Antimicrob Agents Chemother. 2006;50(1):162-170.
48. Shinohara L, de Freitas SF, da Silva RJ, et al. In vitro effects of Crotalus durissus terrificus and Bothrops jararaca venoms on Giardia duodenalis trophozoites. Parasitol Res. 2006;98(4):339-344.

49. Freitas SF, Shinohara L, Sforcin JM, et al. In vitro effects of propolis on Giardia duodenalis trophozoites. Phytomedicine. 2006;13(3): 170-175.

50. Pérez-Arriaga L, Mendoza-Magaña ML, Cortés-Zárate R, et al Cytotoxic effect of curcumin on Giardia lamblia trophozoites. Acta Trop. 2006;98(2):152-161.

51. Busatti HGNO, Vieira AED, Viana JC, et al. Effect of metronidazole analogues on Giardia lamblia cultures. Parasitol Res. 2007;102(1):145-149.

52. Anthony JP, Fyfe L, Stewart D, McDougall GJ, Smith HV. The effect of blueberry extracts on Giardia duodenalis viability and spontaneous excystation of Cryptosporidium parvum oocysts, in vitro. Methods. 2007;42(4):339-348.

53. Calzada F, Alanís AD. Additional antiprotozoal flavonol glycosides of the aerial parts of Helianthemum glomeratum. Phytother Res. 2007;21(1):78-80.

54. Calzada F, Yépez-Mulia L, Aguilar A. In vitro susceptibility of Entamoeba histolytica and Giardia lamblia to plants used in Mexican traditional medicine for the treatment of gastrointestinal disorders. J Ethnopharmacol. 2006;108(3):367-370.

55. Hausen MA, Freitas JC Jr, Monteiro-Leal LH. The effects of metronidazole and furazolidone during Giardia differentiation into cysts. Exp Parasitol. 2006;113(3):135-141.

56. Calzada F. Additional antiprotozoal constituents from Cuphea pinetorum, a plant used in Mayan traditional medicine to treat diarrhoea. Phytother Res. 2005;19(8):725-727.

57. Said Fernández S, Ramos Guerra MC, Mata Cárdenas BD, et al. In vitro antiprotozoal activity of the leaves of Artemisia ludoviciana. Fitoterapia. 2005;76(5):466-468.

58. Andrzejewska M, Yepez-Mulia L, Tapia A, et al. Synthesis, and antiprotozoal and antibacterial activities of S-substituted 4,6-dibromoand 4,6-dichloro-2-mercaptobenzimidazoles. Eur J Pharm Sci. 2004;21(2-3):323-329.

59. Meckes M, Calzada F, Tapia-Contreras A, et al. Antiprotozoal properties of Helianthemum glomeratum. Phytother Res. 1999;13(2):102-105.

60. Lun ZR, Burri C, Menzinger M, et al. Antiparasitic activity of diallyl trisulfide (Dasuansu) on human and animal pathogenic protozoa (Trypanosoma sp., Entamoeba histolytica and Giardia lamblia) in vitro. Ann Soc Belg Med Trop. 1994;74(1):51-59.

61. Boreham PFL, Phillips RE, Shepherd RW. The sensitivity of Giardia intestinalis to drugs in vitro. J Antimicrob Chemother. 1984;14(5):449-461.

62. Reynoldson JA, Thompson RC, Meloni BP. In vivo efficacy of albendazole against Giardia duodenalis in mice. Parasitol Res. 1991;77(4):325-328.

63. Bhopale KK, Pradhan KS, Phaltankar PG, et al. Activity of a new oxadiazole compound, against experimental infections with Entamoeba histolytica and Giardia lamblia in animal models. Ann Trop Med Parasitol. 1993;87(2):169-178.

64. Wahl SM, Gilman RH, O'Hare J, et al. A new miniculture technique for determining in vitro antimicrobial agent sensitivity of axenically cultivated strains of Giardia lamblia. In: Hammond BR, Wallis PM, editors. Advances in Giardia Research. Calgary, Canada: University of Calgary Press; 1988. p. 21-24.

65. Nash T, Rice WG. Efficacies of zinc-finger-active drugs against Giardia lamblia. Antimicrob Agents Chemother. 1998;42(6):1488-1492.

66. Villeneuve V, Beugnet F, Bourdoiseau G. Efficacy of oxfendazole for the treatment of giardiosis in dogs. Experiments in dog breeding kennels. Parasite. 2000;7(3):221-226.

67. Hassan SI, Nessim NG, Mahmoud SS, et al. Effect of a broad spectrum antiparasitic drug "ivermectin" in acute and chronic experimental giardiasis using different dose regimens. J Egypt Soc Parasitol. 2001;31(2):419-428.

68. Langford TD, Housley MP, Boes M, et al. Central importance of immunoglobulin A in host defense against Giardia spp. Infect Immun. 2002;70(1):11-18. 
69. Stein JE, Radecki SV, Lappin MR. Efficacy of Giardia vaccination in the treatment of giardiasis in cats. $J$ Am Vet Med Assoc. 2003;222(11): 1548-1551.

70. El-Taweel HA, El-Zawawy LA, Said DE, et al. Influence of the antioxidant drug (Antox) on experimental giardiasis and microsporidiosis. J Egypt Soc Parasitol. 2007;37(1):189-204.

71. Choudhry VP, Sabir M, Bhide VN. Berberine in giardiasis. Indian Pediatr. 1972;9(3):143-146.

72. Gupte S. Use of berberine in treatment of giardiasis. Am J Dis Child. 1975;129(7):866.

73. Levi GC, Avila CA, Neto VA. Efficay of various drugs for treatment of giardiasis. A comparative study. Am J Trop Med Hyg. 1977;26(3): 564-565.

74. Iyngkaran N, Lee IL, Robinson MJ. Single dose treatment with Tiberal of Giardia lamblia infection in children. Scand J Infect Dis. 1978;10(3):243-246.

75. Jokipii L, Jokipii AM. Comparison of four dosage schedules in the treatment of giardiasis with metronidazole. Infection. 1978;6(2):92-94.

76. Gazder AJ, Banerjee M. Single dose therapy of giardiasis with tinidazole and metronidazole. Drugs. 1978;15 suppl 1:30-32.

77. Farahmandian I, Sheiban F, Sanati A. Evaluation of the effect of a single dose of tinidazole (Fasigyn) in giardiasis. J Trop Med Hyg. 1978;81(7):139-140.

78. Jokipii AM, Jokipii L. Comparative evaluation of two dosages of tinidazole in the treatment of giardiasis. Am J Trop Med Hyg. 1978;27(4):758-761.

79. Kavousi S. Giardiasis in infancy and childhood: a prospective study of 160 cases with comparison of quinacrine (Atabrine) and metronidazole (Flagyl). Am J Trop Med Hyg. 1979;28(1):19-23.

80. Werkman HP, Meuwissen JH. Single-dose treatment of giardiasis with ornidazole in children. Lancet. 1979;2(8156-8157):1373.

81. Sabchareon A, Chongsuphajaisiddhi T, Attanath P. Treatment of giardiasis in children with quinacrine, metronidazole, tinidazole and ornidazole. Southeast Asian J Trop Med Public Health. 1980;11(2):280-284.

82. Craft JC, Murphy T, Nelson JD. Furazolidone and quinacrine. Comparative study of therapy for giardiasis in children. Am J Dis Child. 1981;135(2):164-166

83. Bassily S, Farid Z, el-Masry NA, et al. Treatment of intestinal $E$. histolytica and G. lamblia with metronidazole, tinidazole and ornidazole: a comparative study. J Trop Med Hyg. 1987;90(1):9-12.

84. Cervetto JL, Ramonet M, Nahmod LH, et al. Giardiasis. Functional, immunological and histological study of the small bowel. Therapeutic trial with a single dose of tinidazole. Arq Gastroenterol. 1987;24(2):102-112.

85. Nikolić A, Durković-Daković O, Petrović Z, et al. Effects of age-targeted treatment of intestinal parasite infections in Serbia. $J$ Chemother. 1995;7(1):55-57.

86. Qureshi H, Ali A, Baqai R, et al. Efficacy of a combined diloxanide furoate-metronidazole preparation in the treatment of amoebiasis and giardiasis. J Int Med Res. 1997;25(3):167-170.

87. Agarwal AK, Tripathi DM, Sahai R, et al. Management of giardiasis by a herbal drug 'Pippali Rasayana': a clinical study. J Ethnopharmacol. 1997;56(3):233-236.

88. Penggabean M, Norhayati, Oothuman P, et al. Efficacy of albendazole in the treatment of Trichuris trichuria and Giardia intestinalis infection in rural Malay communities. Med J Malaysia. 1998;53(4):408-412.

89. Qureshi H, Baqai R, Mehdi I, et al. Secnidazole response in amoebiasis and giardiasis. East Mediterr Health J. 1999;5(2):389-390.

90. Di Prisco MC, Jiménez JC, Rodríguez N, et al. Clinical trial with secnidazole in a single dose in Venezuelan children infected by Giardia intestinalis. Invest Clin. 2000;41(3):179-188.

91. Monajemzadeh SM, Monajemzadeh M. Comparison of iron and hematological indices in Giardia lamblia infection before and after treatment in 102 children in Ahwaz, Iran. Med Sci Monit. 2008;14(1):19-23.

92. Bassily S, Farid Z, Mikhail JW, et al. The treatment of Giardia lamblia infection with mepacrine, metronidazole and furazolidone. J Trop Med Hyg. 1970;73(1):15-18.
93. Gazder AJ, Banerjee M. Single-dose treatment of giardiasis in children: a comparison of tinidazole and metronidazole. Curr Med Res Opin. 1977;5(2):164-168.

94. Krishnamurthy KA, Saradhambal V. Single dose therapy of giardiasis: a comparative study of tinidazole and metronidazole in pediatric patients. Indian Pediatr. 1978;15(1):51-56.

95. Masry NA, Farid Z, Miner WF. Treatment of giardiasis with tinidazole. Am J Trop Med Hyg. 1978;27(1 Pt 1):201-202.

96. Kyrönseppä H, Pettersson T. Treatment of giardiasis: relative efficacy of metronidazole as compared with tinidazole. Scand J Infect Dis. 1981;13(4):311-312.

97. Speelman P. Single-dose tinidazole for the treatment of giardiasis. Antimicrob Agents Chemother. 1985;27(2):227-229.

98. Okhuysen PC, DuPont HL, Flores Lopez JF, et al. A comparative study of furazolidone and placebo in addition to oral rehydration in the treatment of acute infantile diarrhea. Scand J Gastroenterol Suppl. 1989;169:39-46.

99. Quiros-Buelna E. Furazolidone and metronidazole for treatment of giardiasis in children. Scand J Gastroenterol Suppl. 1989;169:65-69.

100. Gascon J, Moreno A, Valls ME, et al. Failure of mebendazole treatment in Giardia lamblia infection. Trans R Soc Trop Med Hyg. 1989;83(5):647.

101. Gascon J, Abós R, Valls ME, et al. Mebendazole and metronidazole in giardial infections. Trans R Soc Trop Med Hyg. 1990;84(5):694.

102. Oren B, Schgurensky E, Ephros M, et al. Single-dose ornidazole versus seven-day metronidazole therapy of giardiasis in Kibbutzim children in Israel. Eur J Clin Microbiol Infect Dis. 1991;10(11):963-965.

103. al-Waili NS, Hasan NU. Mebendazole in giardial infection: a comparative study with metronidazole. J Infect Dis. 1992;165(6):1170-1171.

104. Dutta AK, Phadke MA, Bagade AC, et al. A randomised multicentre study to compare the safety and efficacy of albendazole and metronidazole in the treatment of giardiasis in children. Indian J Pediatr. 1994;61(6): 689-693.

105. Misra PK, Kumar A, Agarwal V, et al. A comparative clinical trial of albendazole versus metronidazole in giardiasis. Indian Pediatr. 1995;32(3):291-294.

106. Andrews BJ, Panitescu D, Jipa GH, et al. Chemotherapy for giardiasis: randomized clinical trial of bacitracin, bacitracin zinc, and a combination of bacitracin zinc with neomycin. Am J Trop Med Hyg. 1995;52(4):318-321.

107. Misra PK, Kumar A, Agarwal V, et al. A comparative clinical trial of albendazole versus metronidazole in children with giardiasis. Indian Pediatr. 1995;32(7):779-782.

108. Bulut BU, Gülnar SB, Aysev D. Alternative treatment protocols in giardiasis: a pilot study. Scand J Infect Dis. 1996;28(5):493-495.

109. Pengsaa K, Sirivichayakul C, Pojjaroen-anant C, et al. Albendazole treatment for Giardia intestinalis infections in school children. Southeast Asian J Trop Med Public Health. 1999;30(1):78-83.

110. Sadjjadi SM, Alborzi AW, Mostovfi H. Comparative clinical trial of mebendazole and metronidazole in giardiasis of children. $J$ Trop Pediatr. 2001;47(3):176-178.

111. Rossignol JF, Ayoub A, Ayers MS. Treatment of diarrhea caused by Giardia intestinalis and Entamoeba histolytica or E. dispar: a randomized, double-blind, placebo-controlled study of nitazoxanide. $J$ Infect Dis. 2001;184(3):381-384.

112. Ortiz JJ, Ayoub A, Gargala G, et al. Randomized clinical study of nitazoxanide compared to metronidazole in the treatment of symptomatic giardiasis in children from Northern Peru. Aliment Pharmacol Ther. 2001;15(9):1409-1415.

113. Grant J, Mahanty S, Khadir A. Wheat germ supplement reduces cyst and trophozoite passage in people with giardiasis. Am J Trop Med Hyg. 2001;65(6):705-710.

114. Pengsaa K, Limkittikul K, Pojjaroen-anant C. Single-dose therapy for giardiasis in school-age children. Southeast Asian J Trop Med Public Health. 2002;33(4):711-717.

115. Ozbilgin A, Ertan P, Yereli K, et al. Giardiasis treatment in Turkish children with a single dose of ornidazole. Scand J Infect Dis. 2002;34(12): 918-920. 
116. Escobedo AA, Cañete R, Gonzalez ME, et al. A randomized trial comparing mebendazole and secnidazole for the treatment of giardiasis. Ann Trop Med Parasitol. 2003;97(5):499-504.

117. Escobedo AA, Núñez FA, Moreira I, et al. Comparison of chloroquine, albendazole and tinidazole in the treatment of children with giardiasis. Ann Trop Med Parasitol. 2003;97(4):367-371.

118. Karabay O, Tamer A, Gunduz H et al. Albendazole versus metronidazole treatment of adult giardiasis: An open randomized clinical study. World J Gastroenterol. 2004;10(8):1215-1217.

119. Yereli K, Balcioğlu IC, Ertan P, et al. Albendazole as an alternative therapeutic agent for childhood giardiasis in Turkey. Clin Microbiol Infect. 2004;10(6):527-529.

120. Besirbellioglu BA, Ulcay A, Can M, et al. Saccharomyces boulardii and infection due to Giardia lamblia. Scand J Infect Dis. 2006;38 (6-7):479-481.

121. Canete R, Escobedo AA, Gonzalez ME, et al. Randomized clinical study of five days apostrophe therapy with mebendazole compared to quinacrine in the treatment of symptomatic giardiasis in children. World J Gastroenterol. 2006;12(39):6366-6370.

122. Cañete R, Escobedo AA, González ME, et al. A randomized, controlled, open-label trial of a single day of mebendazole versus a single dose of tinidazole in the treatment of giardiasis in children. Curr Med Res Opin. 2006;22(11):2131-2136.

123. Alizadeh A, Ranjbar M, Kashani KM, et al. Albendazole versus metronidazole in the treatment of patients with giardiasis in the Islamic Republic of Iran. East Mediterr Health J. 2006;12(5):548-554.

124. Lindquist HD. Induction of albendazole resistance in Giardia lamblia. Microb Drug Resist. 1996;2(4):433-434.

125. El-Taweel HA, El-Zawawy LA, Said DE, et al. Influence of the antioxidant drug (Antox) on experimental giardiasis and microsporidiosis. J Egypt Soc Parasitol. 2007;37(1):189-204.

126. Maeda K, Osato T, Umeza H. A new antibiotic: Azomycin. J Antibiot. $1953 ; 6 \mathrm{~A}: 182$

127. Cosar C, Julou L. Activitc de 1 '(hydroxy-2-ethyl)-1-methyl-2-nitro5-imidazole (8,823 RP) vis-à-vis des infections experimentales Trichomonas vaginalis. Ann Inst Pasteur. 1959;96:238-241.

128. Darbon A, Portal A, Girier L, et al. Treatment of giardiasis (lambliasis) with metronidazole. Presse Med. 1962;70:15-16.

129. Gardner TB, Hill DR. Treatment of Giardiasis. Clin Microbiol Rev. 2001;14(1):114-128

130. Boreham PFL, Phillips RE, Shepherd RW. The sensitivity of Giardia intestinalis to drugs in vitro. J Antimicrob Chemother. 1984;14(5): 449-461.

131. Wright CW, Melwani SI, Phillipson JD, et al. Determination of antigiardial activity in vitro by mean of soluble formazan production. Trans R Soc Trop Med Hyg. 1992;86(5):517-519.

132. Kang EW, Clinch K, Furneaux RH, et al. A novel and simple colorimetric method for screening Giardia intetinalis and anti-giardial activity in vitro. Parasitol. 1998;117(Pt 3):229-234.

133. Busatti HGNO, Gomes MA. A simple colourimetric method to determine anti-giardial activity of drugs. Parasitol Res. 2007;101(3):819-821.
134. Sehgal AK, Grewal MS, Chakravarti RN, et al. Experimental giardiasis in albino rats. Indian J Med Res. 1976;64(7):1015-1018.

135. Vinayak VK, Sharma GL, Naik SR. Experimental Giardia lamblia infection in Swiss mice - a preliminary report. Indian J Med Res. 1979;70:195-198.

136. Craft JC, Nelson JD. Diagnosis of giardiasis by counterimmunoeletrophoresis of feces. J Infect Dis. 1982;145(4):499-504.

137. Hill DR, Guerrant RL, Pearson RD, et al. Giardia lamblia infection of suckling mice. J Infect Dis. 1983;147(2):217-221.

138. Schleinitz P, Justus P, Stenzel P, et al. A successful introduction of culture adapted Giardia intestinalis in rabbit model: ultrastructural features. Gastroenterology. 1983;84:1301.

139. Hewlett EL, Andrews JS, Ruffier Jr, et al. Experimental infection of mongrel dogs with Giardia lamblia cysts and cultures trophozoites. J Infect Dis. 1982;145(1):89-93.

140. Kirkpatrick CE, Grenn GA. Susceptibility of domestic cats to infections with Giardia lamblia cysts and trophozoites from human sources. J Clin Microbiol. 1985;21(5):678-680.

141. Barbosa E, Calzada F, Campos R. Antigiardial activity of methanolic extracts from Helianthemum glomeratumLag and Rubus coriifolius Focke in suckling mice CD-1. J Ethnopharmacol. 2006;108(3):395-397.

142. Barbosa E, Calzada F, Campos R. In vivo antigiardial activity of three flavonoids isolated of some medicinal plants used in Mexican traditional medicine for the treatment of diarrhea. J Ethnopharmacol. 2007;109(3):552-554.

143. Belosevic M, Faubert GM, Maclean JD, et al. Giardia lamblia infections in Mongolian Gerbils: an animal model. J Infect Dis. 1983; 147(2):222-226.

144. Araújo NS, Mundim MJS, Gomes MA, et al. Giardia duodenalis: Pathological alterations in gerbils, Meriones unguiculatus, infected with different dosages of trophozoites. Exp Parasitol. 2008;118(4):449-457.

145. Faubert GM, Belosevic M, Walker TS, et al. Comparative studies on the pattern of infection with Giardia spp. In Mongolian gerbils. J Parasitol. 1983;69(5):802-805.

146. Vivesvara GS, Smith PD, Healy GR, et al. An immunofluorescence test to detect serum anibodies to Giardia lamblia. Ann Intern Med. 1988;93(6):802-805.

147. Buret A, Galli DG, Olson ME. Growth, activities of enzymes in the small intestines and ultrastructure of microvillous border in gerbils infected with Giardia duodenalis. Parasitol Res. 1991;77(2):109-114.

148. Mohamed SR, Faubert GM. Dissacharidase deficiencies in Mongolian gerbils (Meriones unguiculatus) protected against Giardia lamblia. Parasitol Res. 1995;81(7):582-590.

149. Zaat JO, Mank TH, Assendelft WJ. WITHDRAWN: Drugs for treating giardiasis. Cochrane Database Syst Rev. 2007;2:CD000217.

150. Escobedo AA, Cimerman S. Giardiasis: a pharmacotherapy review. Expert Opin Pharmacother. 2007;8(12):1885-1902.

151. Upcroft P, Upcroft JA. Drug targets and mechanisms of resistance in the anaerobic protozoa. Clin Microbiol Rev. 2001;14(1):150-164.
Biologics: Targets \& Therapy

\section{Publish your work in this journal}

Biologics: Targets \& Therapy is an international, peer-reviewed journal focusing on the patho-physiological rationale for and clinical application of Biologic agents in the management of autoimmune diseases, cancers or other pathologies where a molecular target can be identified. This journal is indexed on PubMed Central, CAS,

\section{Dovepress}

EMBase, Scopus and the Elsevier Bibliographic databases. The manuscript management system is completely online and includes a very quick and fair peer-review system, which is all easy to use. Visit http://www.dovepress.com/testimonials.php to read real quotes from published authors. 